\title{
The effect of method of fertilizer application on sugar beet yield, yield quality and fertilization requirement in Finland
}

\author{
KYÖSTI RAININKO and MATTI ERJALA
}

Sugar Beet Research Centre, SF-25170 Kotalato, Finland

\begin{abstract}
In 1982 - 1990, the Sugar Beet Research Centre conducted a total of 68 fertilizer placement trials. The present paper deals with 23 trials from five field experiment series. In the evaluation of the results, other experiments conducted at the Sugar Beet Research Centre have also been referred to. The field trials were conducted on experimental farms of the Sugar Beet Research Centre and of sugar factories. The soil type of the experimental fields varied from compact clay to finesand. The soil $\mathrm{pH}$ was high $(6.7-7.4)$ and the nutrient status good. The fertilizer used was an Na-containing compound fertilizer $(\mathrm{N} 13 \%, \mathrm{P} 6 \%, \mathrm{~K} 9 \%$, Na $6 \%$ in 1982-1987; N $15 \%$, P $6 \%, \mathrm{~K} 8 \%$, Na $5 \%$ as from 1988). The fertilizer was applied with a fertilizer drill. A disk bill was used in 1982-1983; thereafter a thin spring tine bill was used.

Placement of fertilizer $3-6 \mathrm{~cm}$ to the side and $3 \mathrm{~cm}$ below the seed increased the root yield of sugar beet by $5-6 \%$, on an average, as compared to broadcasting. The yield increase ranged from 0 to $24 \%$. The yield increase from fertilizer placement correlated negatively with the sugar beet yield level. The nutritional status and humus content of soil, and soil type did not affect the yield increase from fertilizer placement.

The seed bed preparation - one-pass power harrow or conventional method - had no significant effect on the yield increase from fertilizer placement.

Increasing the level of fertilizer reduced the yield increase from fertilizer placement in some of the trials. This was not always the case, however.

Placement usually gave a slightly higher sugar content than did broadcasting.

Placement reduced the potassium content of the beet slightly and increased the extractability of sugar. As compared to broadcasting, placement increased the recoverable sugar yield relatively slightly more than the root yield.

Placement of the fertilizer $3 \mathrm{~cm}$ to the side ( 3 or $6 \mathrm{~cm} \mathrm{~L} \mathrm{'ow} \mathrm{the} \mathrm{seed)} \mathrm{yielded} \mathrm{a} \mathrm{better}$ result than placement $9 \mathrm{~cm}$ to the side of the seed. The depth of placement did not affect the yield.

In most trials, placement of the fertilizer reduced the plant population only slightly as compared to broadcasting. The harmful effect in these trials was not significant even with the smallest distance from the seed, i.e. $3 \mathrm{~cm}$. In practice, placement too close was shown to inhibit or to retard germination of the beet. It is therefore recommended that the fertilizer be placed $5-6 \mathrm{~cm}$ to the side and $3-4 \mathrm{~cm}$ below the seed.
\end{abstract}

Index words: Sugar beet fertilization, Fertilizer application, Placement of fertilizer 


\section{Introduction}

Fertilizer placement is defined as the application of fertilizer to the soil, in one or two rows on one or both sides of the seed row. Sometimes the term fertilizer placement is used whenever the fertilizer is applied under the soil surface.

The crop improvement resulting from placement of fertilizer in cultivation of sugar beet has been studied in several countries. In the first trials the fertilizer was mixed with the seed. Actual fertilizer placement trials were conducted by COOKE (1949, 1951), in England as early as in the late 1940s, and by LÜDECKE, SChefFer and TiedemanN (1956) in Germany in the early 1950s. Although the results indicated that placement of fertilizer brought about some increase in yield, it has not generally been recommended; instead, it has been considered, e.g. to make the sowing process slower and to inhibit germination by breaking the seed bed (Draycotr 1972).

In the 1960s, several trials on sugar beet comparing broadcasting with placement at a certain depth immediately before sowing, using a fertilizer drill, were conducted in Finland. The distance between the fertilizer and seed rows in these trials was not fixed; it ranged from 0 to $25 \mathrm{~cm}$. Such random placement did not increase the yield sufficiently (ANON 1970). Although placement of fertilizer became increasingly popular in grain crop growing in the early 1970 s, broadcasting has been the main method of fertilizer application for sugar beet.

The shortness of the growth period in Finland is a major factor limiting beet yields. It is therefore very important that sowing be done as early as possible, especially on clay and silt soils, which are the dominant soil types in Southwestern Finland, the main site of sugar beet cultivation. Only early sowing can prevent some of the valuable growth period from being lost unnecessarily by waiting for the soil to dry adequately for seed bed preparation and sowing. To enable early sowing and to avoid soil compaction, develop- ment of a one-pass method was started in the early 1980s at the Sugar Beet Research Centre. In this method, seed bed preparation, fertilization and sowing are done simultaneously (Raininko 1981, 1988, ErJala 1984, ErJala \& RAININKO 1985), using a fertilizer drill designed and built specifically for this purpose. A single-disk bill was initially used as the fertilizing bill, but very soon, in 1983, it was replaced by a thin bill with a stiff spring tine bill. After the preliminary experiments in 1980 - 1981, actual fertilizer placement trials started in 1982. Similar trials were also performed simultaneously in Sweden (TRÖNNBERG 1983). Later, at the end of the 1980s, when discussions about reducing the use of fertilizers to minimize leaching of nutrients was started, placement of fertilizer gained increasing popularity everywhere.

\section{Materials and methods}

The placement trials were conducted with a 7- or 8-row fertilizer drill. A seed unit was attached to the back of the drill, to make the distance and depth of the fertilizer row adjustable in relation to the seed row. Unless otherwise stated, the fertilizer was placed $6 \mathrm{~cm}$ to the side and $3 \mathrm{~cm}$ below the seed row. The fertilizer used was an Na-containing compound fertilizer. In 1982-1987, it contained $13 \% \mathrm{~N}, 6 \% \mathrm{P}, 9 \% \mathrm{~K}$ and $6 \% \mathrm{Na}$; from 1988 on, the composition of the fertilizer has been $15 \%, 6 \%, 8 \%$ and $5 \%$, respectively. Broadcasting has been performed with the same fertilizer unit, but allowing the fertilizer to drop straight from fertilizer tubes onto the soil surface. Thus it was possible to ensure that the same quantities were applied by both methods of application. The fertilizer bills were fed by two fertilizer tubes to make the spreading of fertilizer even.

The seed beds were prepared normally, either by harrowing twice or three times with a Dutch harrow or once with a power harrow. The sugar beet was sown to stand, at a seed distance of $15 \mathrm{~cm}$ and row distance of $48 \mathrm{~cm}$. The variety used was mostly Salohill in 1985 
and 1986; in some trials the cultivar Ovatio was also used.

The plots consisted of seven $10-\mathrm{m}$ rows, and only the sugar beets grown on the two rows in the middle of the plot were harvested. The crops were harvested in September-October. The weather data presented in Tables 1 and 2 are those from Salo meteorological station. Although the temperatures and precipitation differed to some extent between the study locations, the weather data from Salo probably give an adequate picture of the weather conditions prevailing during the experiments.

In Finland, extractable white sugar is calculated by the slightly modified version of Reinefeld's equation:

$100 \times \frac{\mathrm{Pol}-0.343(\mathrm{~K}+\mathrm{Na})-0.00671 \mathrm{~N}-0.69}{\mathrm{Pol}}$

where

$\mathrm{K}=$ Potassium meq/100 $\mathrm{g}$ beet

$\mathrm{Na}=$ Sodium "

$\mathrm{N}=$ aminonitrogen $\mathrm{mg} / 100 \mathrm{~g}$ beet

In the Tables, statistical significance is in-

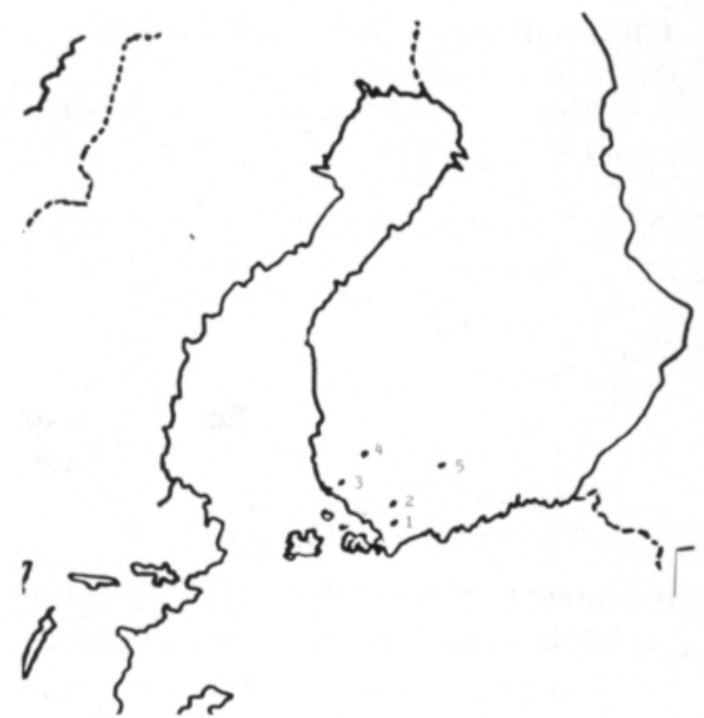

Fig. 1. Experimental fields. 1 Perniō, 2 Salo, 3 Mietoinen, 4 Köyliō, 5 Turenki

dicated by common letters. The same letter indicates no significant difference between the figures. In the analysis of variance, the significance of F-values is indicated normally by an asterisk. The experimental fields are presented in Figure 1.

Table 1. Mean temperature from May to September in Salo in 1982-89.

\begin{tabular}{lrrrrrrrrr}
\hline Month & \multicolumn{7}{c}{ Mean temperature ${ }^{\circ} \mathrm{C}$} \\
\cline { 2 - 10 } & $1931-$ & 1982 & 1983 & 1984 & 1985 & 1986 & 1987 & 1988 & 1989 \\
& 1960 & & & & & & 13.3 & & 12.1 \\
V & 9.7 & 9.1 & 11.6 & 13.3 & 9.8 & 10.9 & 8.3 & 11.1 \\
VI & 14.3 & 12.2 & 14.1 & 14.5 & 14.4 & 17.3 & 12.8 & 17.7 & 16.5 \\
VII & 17.4 & 17.4 & 17.6 & 15.6 & 16.3 & 17.1 & 15.9 & 19.5 & 17.3 \\
VIII & 16.0 & 16.7 & 15.7 & 15.0 & 16.4 & 13.9 & 12.5 & 14.8 & 14.8 \\
IX & 10.7 & 10.9 & 12.0 & 10.2 & 9.8 & 7.5 & 9.3 & 11.7 & 11.8 \\
\hline
\end{tabular}

Table 2. Precipitation from May to September in Salo in 1982-89.

\begin{tabular}{lcccccccrr}
\hline Month & \multicolumn{7}{c}{ Precipitation } \\
\cline { 2 - 9 } & $1931-$ & 1982 & 1983 & 1984 & 1985 & 1986 & 1987 & 1988 & 1989 \\
& 1960 & & & & & & & & \\
\hline V & 36 & 61 & 33 & 64 & 55 & 48 & 56 & 46 & 34 \\
VI & 39 & 17 & 50 & 99 & 61 & 26 & 73 & 49 & 43 \\
VII & 78 & 71 & 44 & 84 & 52 & 72 & 51 & 192 & 75 \\
VIII & 72 & 97 & 41 & 64 & 141 & 126 & 114 & 111 & 89 \\
IX & 84 & 32 & 85 & 68 & 57 & 125 & 101 & 72 & 25 \\
\hline
\end{tabular}


Trial on the amounts of fertilizer and methods of application in $\mathbf{1 9 8 2}$

\section{Design}

The first trial on the amounts of fertilizer and methods of application was carried out in 1982 at Perniö. The trial design was as follows:

A. Method of application

$a_{1}$ Broadcasting

$a_{2}$ Placement

B. Amount of fertilizer

$b_{1}$ Na-containing compound fertilizer, $625 \mathrm{~kg} / \mathrm{ha}(=82 \mathrm{~kg} \mathrm{~N})$

$\mathrm{b}_{2}$ Na-containing compound fertilizer, $860 \mathrm{~kg} / \mathrm{ha}(=112 \mathrm{~kg} \mathrm{~N})$

The soil of the trial field was silty clay of poor nutrient status. The previous crop had been ley.

\section{Results}

The results (Table 3) showed that placement of fertilizer increased beet yield highly significantly, especially at the lower fertilization level. It also had a slightly positive effect on the sugar content of the beet.

Trial with different amounts of fertilizer and methods of application in 1983-1985

\section{Design}

In 1983, new field trials were designed in order to compare the broadcasting and placement at different fertilization levels. The trial was carried out on three experimental farms in Southern Finland, at Salo, Mietoinen and Köyliö. The soil type was silty clay at Salo and Mietoinen, and finesand at Köyliö. The humus content was $6-8 \%$ at Salo, $3-4 \%$ at the other two locations. The nutrient status

Table 3. Trial with different amounts of fertilizer and methods of application in 1982: yields and yield quality.

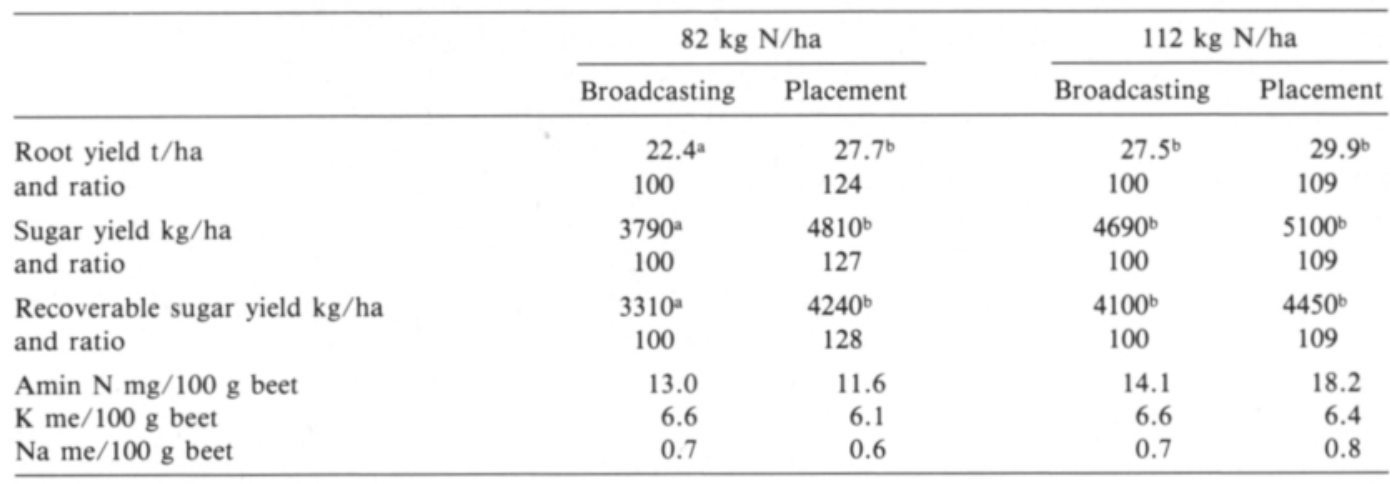

Table 4. Effect of application methods on root yields at different locations in 1983-1985.

\begin{tabular}{|c|c|c|c|c|c|c|}
\hline \multirow[t]{3}{*}{ Trial place } & \multicolumn{6}{|c|}{ Root yield $\mathrm{t} / \mathrm{ha}$} \\
\hline & \multicolumn{2}{|c|}{1983} & \multicolumn{2}{|c|}{1984} & \multicolumn{2}{|c|}{1985} \\
\hline & Broadc. & Placement & Broadc. & Placement & Broadc. & Placement \\
\hline Mietoinen & 35.4 & 35.9 & 40.3 & $45.3 * * *$ & 33.4 & $35.6^{*}$ \\
\hline Salo & 42.2 & $44.4^{* *}$ & 35.4 & $37.8^{* * *}$ & 27.0 & $28.9^{*}$ \\
\hline Köyliö & 36.3 & 36.3 & 29.5 & 30.1 & 32.9 & 33.2 \\
\hline Mean & 38.0 & $39.2 * *$ & 35.0 & $37.7^{* * *}$ & 31.1 & $32.6 * * *$ \\
\hline Ratio & 100 & 103 & 100 & 108 & 100 & 105 \\
\hline
\end{tabular}

* Signif. diff., method of application 


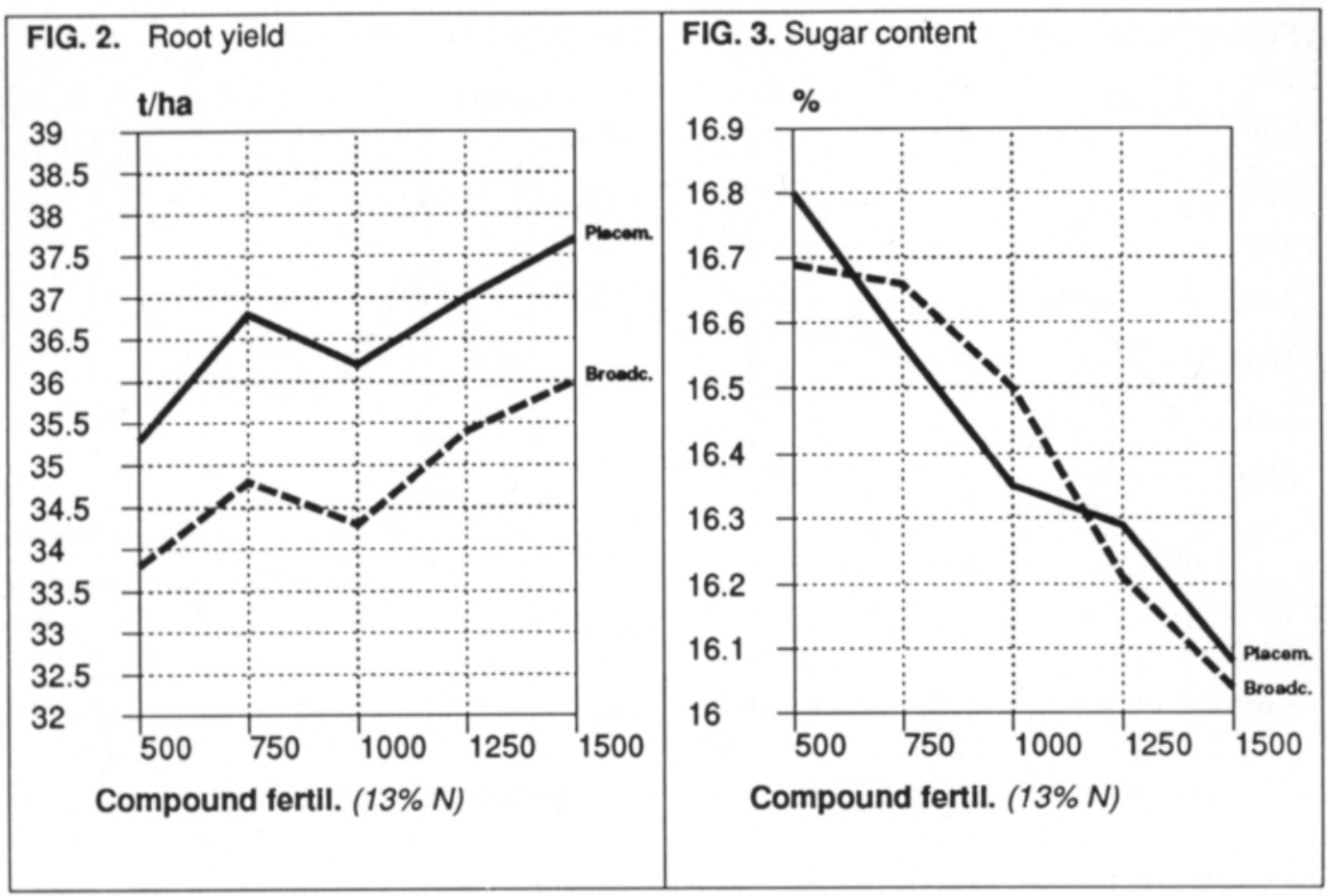

Fig. 2-3. Root yields and sugar contents in trials with different amounts of fertilizer and methods of application (means of 9 trials).

of the soil was good at all trial locations (extremely good at Köyliö). The sowing time was quite late at all locations, ranging from May 11 to 16 at Mietoinen, from May 12 to 21 at Salo and from May 24 to June 3 at Köyliö. The trial crops were harvested every year at the turn of September-October. The fertilizer used was an Na-containing compound fertilizer.

The trial design was as follows:

A. Method of application
$a_{1}$ Broadcasting
$a_{2}$ Placement

B. Amount of fertilizer

$b_{1} 500 \mathrm{~kg} / \mathrm{ha} \mathrm{Na-containing} \mathrm{compound}$ fertilizer $=65 \mathrm{~kg} \mathrm{~N} / \mathrm{ha}$

$b_{2} 750 \mathrm{~kg} / \mathrm{ha} \mathrm{Na-containing} \mathrm{compound}$ fertilizer $=97.5 \mathrm{~kg} \mathrm{~N} / \mathrm{ha}$

$\mathrm{b}_{3}$ 1,000 kg/ha Na-containing compound fertilizer $=130 \mathrm{~kg} \mathrm{~N} / \mathrm{ha}$

$\mathrm{b}_{4} 1,250 \mathrm{~kg} / \mathrm{ha} \mathrm{Na-containing} \mathrm{compound}$ fertilizer $=162.5 \mathrm{~kg} \mathrm{~N} / \mathrm{ha}$ $\mathrm{b}_{5}$ 1,500 kg/ha Na-containing compound fertilizer $=195 \mathrm{~kg} \mathrm{~N} / \mathrm{ha}$

\section{Results}

Placement of fertilizer clearly increased the beet yield at Mietoinen and Salo. At Köyliö there was no increase in beet yield, or it was small (Table 4). The result was similar in all years of the trial. Fertilization increased root yield even with the highest fertilization level used for the trials. The fertilization level did not, however, have any effect on the yield increase obtained by placement of fertilizer (Fig. 2).

Placement of fertilizer had a minor effect on the sugar content (Fig. 3) and a slightly, but not significantly, negative effect on the percent extraction (Fig. 6) due to the fact that in 1984 placement of fertilizer seemed to increase the aminonitrogen content of sugar beet. The method of application had no effect on the potassium and sodium contents of sugar beet. 


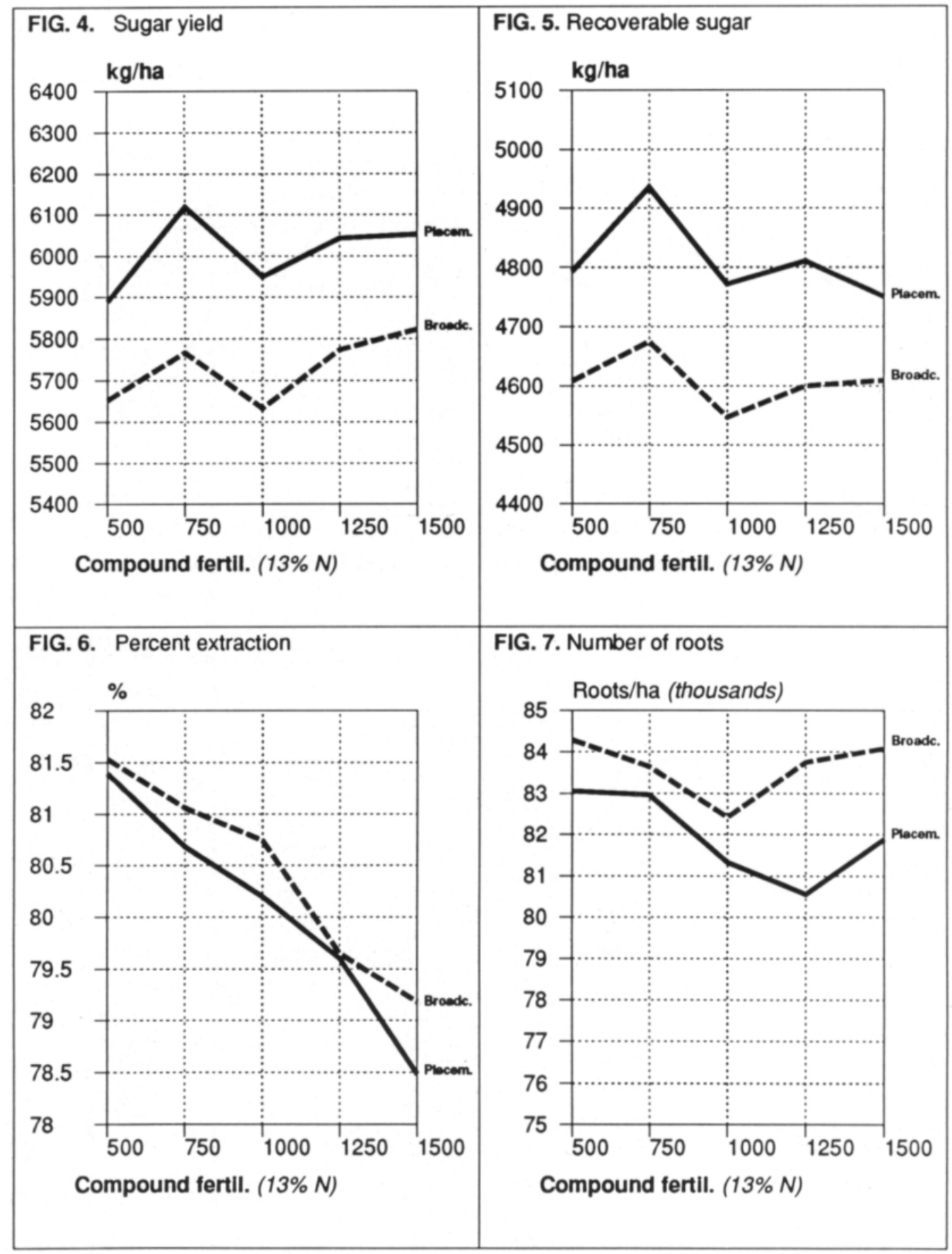

Fig. 4-7. Results from trials with different amounts of fertilizer and methods of application in $1983-85$ (9 trials).

Placement of fertilizer increased the sugar yield and recoverable sugar yield in the same proportion as it increased the root yield (Fig.
4 and 5).

The best sugar and recoverable sugar yields were obtained with the second lowest fertili- 
zation level $(97.5 \mathrm{~kg} \mathrm{~N} / \mathrm{ha})$. The difference from the reference level was significant. Further increase of fertilization had a slightly negative effect.

Placement fertilization seemed to have a very slight negative effect on the number of sugar beets (Fig. 7).

\section{Trial with different methods of application} on spring-ploughed fields in 1985-1987

\section{Design}

In Finland, finesand and other light soil fields used for sugar beet cultivation are usually ploughed in spring. The fertilizer is most commonly applied before ploughing. The aim of the experiment done in 1985-1987 was to establish the effect of placement of fertilizer as compared to broadcasting before or after ploughing. The experiment was conducted at Turenki in 1985-1987, at Köyliö in 1985 and 1987 and at Mietoinen in 1986-1987. The ex- perimental field was coarse finesand, and the humus content was $3-6 \%$. The nutrient status at all locations was quite good, and the $\mathrm{pH}$ adequately high for sugar beet. The plots were sown to stand, at a seed distance of 15 $\mathrm{cm}$. The fertilizer used was an Na-containing compound fertilizer, $1,000 \mathrm{~kg} / \mathrm{ha}(130 \mathrm{~kg}$ $\mathrm{N} / \mathrm{ha}$ ). In 1986, the plots were sown in midMay, in the other years at the end of May.

The trial members were as follows:

1 Broadcasting before ploughing

2 Broadcasting after ploughing

3 Placement in association with sowing

\section{Results}

Placement of fertilizer gave an average increase of $9 \%$ in root yield when compared to broadcasting after ploughing (Table 5). Placement gave the best yields in all experimental years, although the differences from other treatments were not always signifi-

Table 5. Trials with different methods of application in 1985-87: yield-and qualities.

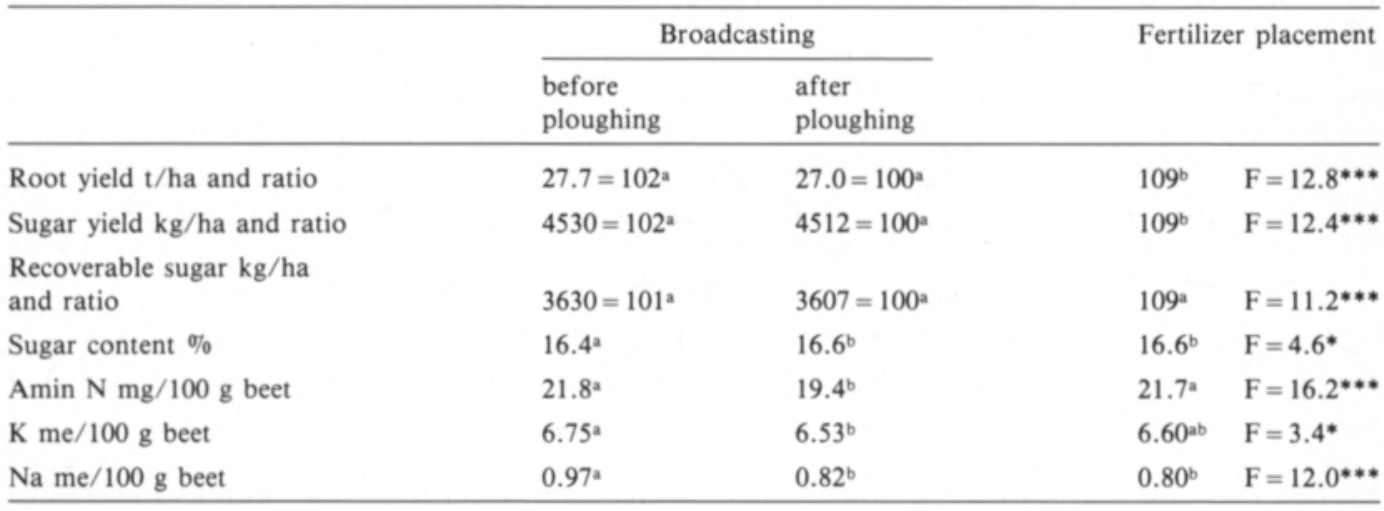

Table 6. Trials with different methods of application. Root yields in 1985-1987.

\begin{tabular}{|c|c|c|c|c|}
\hline \multirow[t]{2}{*}{ Year } & \multicolumn{2}{|c|}{ Broadcasting } & \multirow{2}{*}{\multicolumn{2}{|c|}{$\begin{array}{l}\text { Fertilizer placement } \\
\text { ratio }\end{array}$}} \\
\hline & $\begin{array}{c}\text { before } \\
\text { ploughing } \\
\text { t/ha }\end{array}$ & $\begin{array}{l}\text { after } \\
\text { ploughing } \\
\text { ratio }\end{array}$ & & \\
\hline 1985 & $96^{a}$ & $26.6=100^{\mathrm{a}}$ & $107^{b}$ & $\mathrm{~F}=8.4^{* *}$ \\
\hline 1986 & $110^{b}$ & $31.5=100^{\mathrm{a}}$ & $112^{\mathrm{b}}$ & $\mathrm{F}=17.6^{* * *}$ \\
\hline 1987 & 99a & $21.5=100^{a}$ & $103^{a}$ & $\mathrm{~F}=0.9$ \\
\hline
\end{tabular}


cant (Table 6). Broadcasting after ploughing gave the clearly poorest result in 1986, a year of spring draught.

The differences in yield quality were slight on average. Application of fertilizer to the surface before ploughing gave, however, mostly a slightly poorer quality than did the other methods (Table 5).

\section{Trials with different application methods and seed bed preparation}

\section{Design}

In 1987-1989, a trial was carried out to investigate the effect of placement of fertilizer when using the conventional uncontrolled wheeling system and the one-pass method (harrowing, fertilizer application and seed drilling). Three fertilization levels - 460, 730 and $1,000 \mathrm{~kg} / \mathrm{ha}$ - were used; the fertilizer was a compound fertilizer (15\% N, $6 \% \mathrm{P}$, $8 \% \mathrm{~K}, 5 \% \mathrm{Na}, 0.2 \% \mathrm{~B}$ and $0.7 \% \mathrm{Mn}$ ). These fertilizer amounts contained nitrogen 70,110 and $150 \mathrm{~kg} / \mathrm{ha}$, respectively. The 1987 trial was conducted at Perniö, those after 1987 at Mietoinen. In 1988, the experimental field was finesand; in the other years it was sandy clay. The nutrient status in all fields was good. The trial followed the split plot method, the seed bed preparation method being applied in the main plots and the other factors in the subplots.

The trial design was as follows:
A. Seed bed preparation
$a_{1}$ Conventional
$a_{2}$ One-pass method
B. Method of fertilizer application
$\mathrm{b}_{1}$ Broadcasting
$b_{2}$ Placement

Table 7. Trials with different application methods and seed bed preparation: root yields and sugar content given by placement comparing with broadcasting.

\begin{tabular}{|c|c|c|c|c|c|c|c|c|c|}
\hline \multirow[t]{2}{*}{$\begin{array}{l}\text { Seed bed } \\
\text { prep. }\end{array}$} & \multirow[t]{2}{*}{ Application method } & \multicolumn{4}{|c|}{$\begin{array}{l}\text { Root yield } \mathrm{t} / \mathrm{ha} \\
\text { and ratio }\end{array}$} & \multicolumn{4}{|c|}{ Per cent sugar } \\
\hline & & $70 \mathrm{~N}$ & $110 \mathrm{~N}$ & $150 \mathrm{~N}$ & Mean & $70 \mathrm{~N}$ & $110 \mathrm{~N}$ & $150 \mathrm{~N}$ & Mean \\
\hline Conventional & $\begin{array}{l}\text { Broadcasting } \\
\text { Placement }\end{array}$ & $\begin{array}{l}32.6 \\
106^{*}\end{array}$ & $\begin{array}{l}36.5 \\
101\end{array}$ & $\begin{array}{l}36.5 \\
105^{*}\end{array}$ & $\begin{array}{c}35.2 \\
104^{* * * *}\end{array}$ & $\begin{array}{r}17.72 \\
+0.15\end{array}$ & $\begin{array}{r}17.57 \\
+0.07\end{array}$ & $\begin{array}{c}17.22 \\
+0.26^{*}\end{array}$ & $\begin{array}{r}17.50 \\
+0.16\end{array}$ \\
\hline One pass & $\begin{array}{l}\text { Broadcasting } \\
\text { Placement }\end{array}$ & $\begin{array}{c}35.0 \\
109 * * *\end{array}$ & $\begin{array}{l}36.4 \\
104^{*}\end{array}$ & $\begin{array}{l}37.5 \\
104^{*}\end{array}$ & $\begin{array}{c}36.3 \\
106^{* * * *}\end{array}$ & $\begin{array}{c}17.59 \\
+0.39^{*}\end{array}$ & $\begin{array}{r}17.42 \\
+0.14\end{array}$ & $\begin{array}{r}17.29 \\
+0.26\end{array}$ & $\begin{aligned} & 17.43 \\
+ & 0.24^{*}\end{aligned}$ \\
\hline F-values & $\begin{array}{l}\text { Seed bed preparation } \\
\text { Method of application } \\
\text { Amount of fertilizer }\end{array}$ & & $\begin{array}{r}8.64^{*} \\
12.42^{*} \\
10.74^{*}\end{array}$ & & & $\begin{array}{c}0.01 \\
8.53^{* *} \\
10.63^{* *}\end{array}$ & & & \\
\hline
\end{tabular}

Table 8. Trials with different application methods and seed bed preparations: sugar yields and per cent extraction given by placement comparing with broadcasting.

\begin{tabular}{|c|c|c|c|c|c|c|c|c|c|}
\hline \multirow[t]{2}{*}{ Seed bed prepar. } & \multirow[t]{2}{*}{ Application method } & \multicolumn{4}{|c|}{ Sugar yield $\mathrm{kg} / \mathrm{ha}$} & \multicolumn{4}{|c|}{ Per cent extraction } \\
\hline & & $70 \mathrm{~N}$ & $110 \mathrm{~N}$ & $150 \mathrm{~N}$ & Mean & $70 \mathrm{~N}$ & $110 \mathrm{~N}$ & $150 \mathrm{~N}$ & Mean \\
\hline Conventional & $\begin{array}{l}\text { Broadcasting } \\
\text { Placement }\end{array}$ & $\begin{array}{l}5890 \\
106^{*}\end{array}$ & $\begin{array}{r}6500 \\
101\end{array}$ & $\begin{array}{c}6330 \\
107^{*}\end{array}$ & $\begin{array}{l}6240 \\
105^{* *}\end{array}$ & $\begin{array}{r}83.4 \\
+0.4\end{array}$ & $\begin{array}{r}82.9 \\
+0.9\end{array}$ & $\begin{array}{r}82.1 \\
+0.8\end{array}$ & $\begin{array}{c}82.8 \\
+0.7^{*}\end{array}$ \\
\hline One pass & $\begin{array}{l}\text { Broadcasting } \\
\text { Placement }\end{array}$ & $\begin{array}{l}6220 \\
111^{* *}\end{array}$ & $\begin{array}{c}6420 \\
105^{*}\end{array}$ & $\begin{array}{r}6530 \\
105\end{array}$ & $\begin{array}{l}6390 \\
107^{* * *}\end{array}$ & $\begin{array}{r}83.3 \\
+0.5\end{array}$ & $\begin{array}{r}82.6 \\
+0.9\end{array}$ & $\begin{array}{r}82.1 \\
+0.9\end{array}$ & $\begin{array}{c}82.7 \\
+0.8^{*}\end{array}$ \\
\hline F-values & $\begin{array}{l}\text { Seed bed preparation } \\
\text { Application method } \\
\text { Amount of fertilizer }\end{array}$ & & $\begin{array}{r}6.0 \\
17.2 \\
3.9\end{array}$ & $* * *$ & & & $\begin{array}{r}0.53 \\
16.08 \\
10.48\end{array}$ & $* *$ & \\
\hline
\end{tabular}


C. Amount of fertilizer

$c_{1} 460 \mathrm{~kg} / \mathrm{ha}=70 \mathrm{~N}$

$c_{2} 730 \mathrm{~kg} / \mathrm{ha}=110 \mathrm{~N}$

c $1000 \mathrm{~kg} / \mathrm{ha}=150 \mathrm{~N}$

Sowing was done on May 27, 1987, on May 15, 1988 and on May 6, 1989.

\section{Results}

Placement of fertilizer almost always increased the root yield (Table 7). The increase in root yield averaged $5 \%$. The highest increase, $7 \%$, was obtained in 1987 , when the yield was exceptionally low. The increase was $5 \%$ in 1988 and $3 \%$ in 1989 . The increase in yield obtained by placement of fertilizer seemed to be slightly higher for the combina- tion sowing $(+6 \%)$ than for conventional seed bed preparation $(+4 \%)$. Similarly, it seemed that placement of fertilizer yielded a higher benefit at the lowest fertilization level. However, none of the combined effects was statistically significant.

In the present trials, placement of fertilizer increased the sugar content of the beets (average 0.2 percentage points) and the extractability of sugar (average 0.8 percentage points) (Tables 7 and 8). The latter increase was primarily due to the reduced potassium content. As a result of the improvement in quality, placement of fertilizer increased the sugar yield and recoverable sugar yield relatively slightly more than it increased the root yield.

The one-pass method produced an average increase of $4 \%$ in root yield when compared

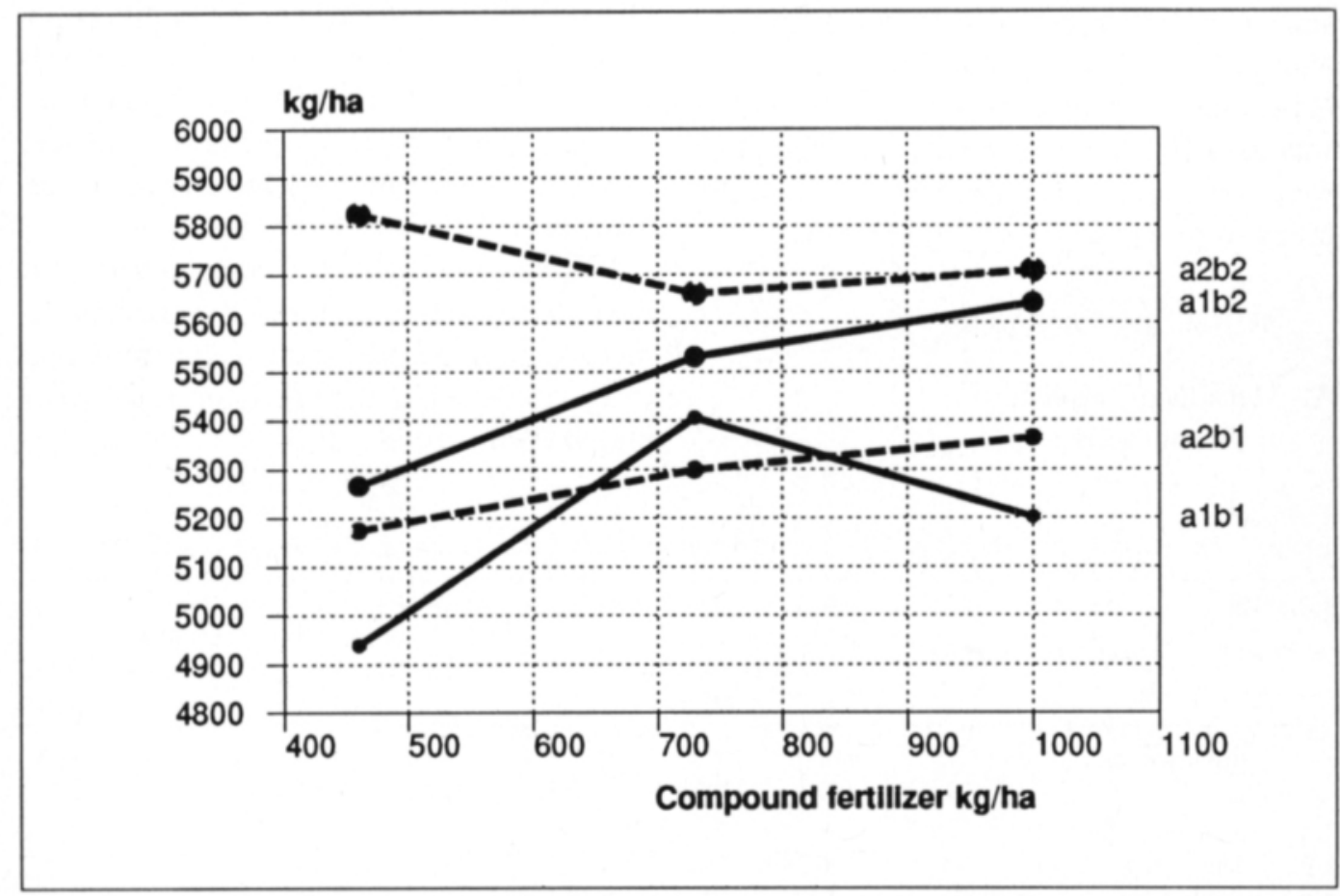

$$
\begin{array}{ll}
a_{1} b_{1}=\text { Conventional } & + \text { broadcasting } \\
a_{1} b_{2}=\text { Conventional } & + \text { fertilizer placement } \\
a_{2} b_{1}=\text { One pass method } & + \text { broadcasting } \\
a_{2} b_{2}=\text { One pass method } & + \text { fertilizer placement }
\end{array}
$$

Fig. 8. The effect of seed bed preparation and method of fertilizer application on recoverable sugar yield $(3$ trials in $1987-89$ ). 
to the conventional cultivation technique. The method of preparing the seed bed had no notable effect on the quality of sugar beet.

The higher levels of fertilizer increased the root yield even with the highest amount used. However, it had a negative effect on the quality of the sugar beet to the extent that increasing fertilization from the middle level to the highest no longer increased the recoverable sugar yield, or else the increase was very slight, and by no means significant (Fig. 8).

\section{The effect of the place of fertilizer row}

\section{Design}

In 1983-1985, the effect of the place of the fertilizer row on sugar beet was tested in three field trials at Perniö. The trials were established on a pre-levelled trial area, using a combination of fertilizer-drill and seed units. The soil of the experimental field was silty clay, and the nutrient status was moderately good. $\mathrm{Na}$-containing compound fertilizer (15-6-8-5) was used $1000 \mathrm{~kg} / \mathrm{ha}$. In each year the plots were sown on the last week of May, and the crops were harvested in early October.

The trial members were:

A. Method of application

$a_{1}$ Broadcasting $a_{2}$ Placement on one side of the seed row $=1$ fertilizer row

$a_{3}$ Placement on both sides of the seed row $=2$ fertilizer rows

B. Depth

$b_{1} 3 \mathrm{~cm}$ below the seed

$b_{2} 6 \mathrm{~cm}$ below the seed

C. Distance

$\mathrm{c}_{1} 3 \mathrm{~cm}$ to the side of the seed

$c_{2} 9 \mathrm{~cm}$ to the side of the seed

The trial thus consisted of seven trial members, with broadcasting as the reference method.

\section{Results}

Fertilizer placement increased the sugar beet yield and sugar content in all years. It also had a slightly positive effect on the quality of sugar beet (Table 9). Placement of fertilizer increased the recoverable sugar yield relatively more than the root yield (Figs. 9 and 10).

One row of fertilizer placed next to the seed row gave a result as good as fertilizer placement on both sides of the seed row.

Placement of fertilizer 3 or $6 \mathrm{~cm}$ below the seed yielded the same result, whereas placement $3 \mathrm{~cm}$ to the side of the seed row in most cases produced a better result than when placed $9 \mathrm{~cm}$ to the side.

Table 9. The effect of the number and location of fertilizer rows on the sugar beet yield and quality in $1983-85$.

\begin{tabular}{|c|c|c|c|c|c|c|c|c|}
\hline \multicolumn{2}{|c|}{ Treatment } & \multirow{2}{*}{$\begin{array}{c}\begin{array}{c}\text { Root } \\
\text { yield } \\
\text { t/ha and } \\
\text { ratio }\end{array} \\
28.2\end{array}$} & \multirow{2}{*}{$\begin{array}{c}\begin{array}{c}\text { Sugar } \\
\text { yield } \\
\mathrm{kg} / \mathrm{ha} \text { and } \\
\text { ratio }\end{array} \\
4480\end{array}$} & \multirow{2}{*}{$\begin{array}{l}\text { Per cent } \\
\text { sugar }\end{array}$} & \multirow{2}{*}{$\begin{array}{c}\text { Amin } N \\
\mathrm{mg} / 100 \mathrm{~g} \\
\text { beet }\end{array}$} & \multirow{3}{*}{$\begin{array}{c}\mathrm{K} \\
\begin{array}{c}\mathrm{me} / 100 \mathrm{~g} \\
\text { beet }\end{array} \\
6.01^{\mathrm{a}}\end{array}$} & \multirow{3}{*}{$\begin{array}{c}\mathrm{Na} \\
\mathrm{me} / 100 \mathrm{~g} \\
\text { beet }\end{array}$} & \multirow{3}{*}{$\begin{array}{c}\begin{array}{c}\text { Number } \\
\text { of } \\
\text { beets/ha }\end{array} \\
84.3 \\
100^{a}\end{array}$} \\
\hline$a_{0}$ & Broadcasting & & & & & & & \\
\hline & & $100^{\mathrm{a}}$ & $100^{\mathrm{ac}}$ & $15.84^{\mathrm{a}}$ & $23.3^{a}$ & & & \\
\hline & 1 fertilizer row & & & & & & & \\
\hline$a_{1} b_{3} c_{3}$ & depth $3 \mathrm{~cm}$, distance $3 \mathrm{~cm}$ & $100^{\circ}$ & $100^{\circ}$ & $15.92^{a}$ & $24.6^{4}$ & $3.98^{\circ}$ & $1.00^{\circ}$ & $95^{\mathrm{a}}$ \\
\hline$a_{a} b_{3} c_{9}$ & depth $3 \mathrm{~cm}$, distance $9 \mathrm{~cm}$ & $104^{\mathrm{a}}$ & $104^{b c}$ & $15.83^{\mathrm{a}}$ & $26.0^{b}$ & $5.91^{\mathrm{a}}$ & $1.08^{\mathrm{a}}$ & $97^{a}$ \\
\hline$a_{1} b_{6} c_{3}$ & depth $6 \mathrm{~cm}$, distance $3 \mathrm{~cm}$ & $109^{b}$ & $110^{b}$ & $16.00^{\mathrm{a}}$ & $24.7^{a}$ & $5.87^{a}$ & $1.01^{\mathrm{a}}$ & $96^{\mathrm{a}}$ \\
\hline$a_{1} b_{6} c_{9}$ & depth $6 \mathrm{~cm}$, distance $9 \mathrm{~cm}$ & $104^{a}$ & $104^{b c}$ & $15.87^{\mathrm{a}}$ & $25.7^{\mathrm{a}}$ & $5.84^{\mathrm{a}}$ & $1.02^{\mathrm{a}}$ & $98^{\mathrm{a}}$ \\
\hline$a_{a} b_{3} c_{3}$ & $\begin{array}{l}2 \text { fertilizer rows } \\
\text { depth } 3 \mathrm{~cm} \text {, distance } 3 \mathrm{~cm}\end{array}$ & $104^{b}$ & $105^{\mathrm{bc}}$ & $16.01^{\mathrm{a}}$ & $24.7^{a}$ & $5.66^{\mathrm{b}}$ & $0.95^{\mathrm{a}}$ & $97^{a}$ \\
\hline$a_{2} b_{3} c_{9}$ & depth $3 \mathrm{~cm}$, distance $9 \mathrm{~cm}$ & 106 & $106^{\mathrm{bc}}$ & $15.88^{\mathrm{a}}$ & $26.0^{b}$ & $5.94^{a}$ & $0.99^{\mathrm{a}}$ & $99^{a}$ \\
\hline$a_{2} b_{6} c_{3}$ & depth $6 \mathrm{~cm}$, distance $3 \mathrm{~cm}$ & $106^{\mathrm{b}}$ & $106^{\mathrm{bc}}$ & $16.04^{\mathrm{a}}$ & $24.3^{\mathrm{a}}$ & $5.80^{\mathrm{b}}$ & $1.02^{\mathrm{a}}$ & $94^{\mathrm{a}}$ \\
\hline$a_{2} b_{6} c_{9}$ & depth $6 \mathrm{~cm}$, distance $9 \mathrm{~cm}$ & $103^{a}$ & $103^{a c}$ & $15.85^{a}$ & $23.6^{a}$ & $5.91^{x}$ & $1.03^{\mathrm{a}}$ & $101^{\mathrm{a}}$ \\
\hline
\end{tabular}


Placement of fertilizer seemed to cause a slight reduction in the plant population. Placement of the fertilizer $3 \mathrm{~cm}$ to the side of the seed had a slightly greater effect than did placement $9 \mathrm{~cm}$ to the side. The differences were not, however, statistically significant.

\section{Discussion}

In the present experiments, fertilizer placement almost invariably increased the sugar beet yield as compared to broadcasting. The mean yield increase for all the experiments was

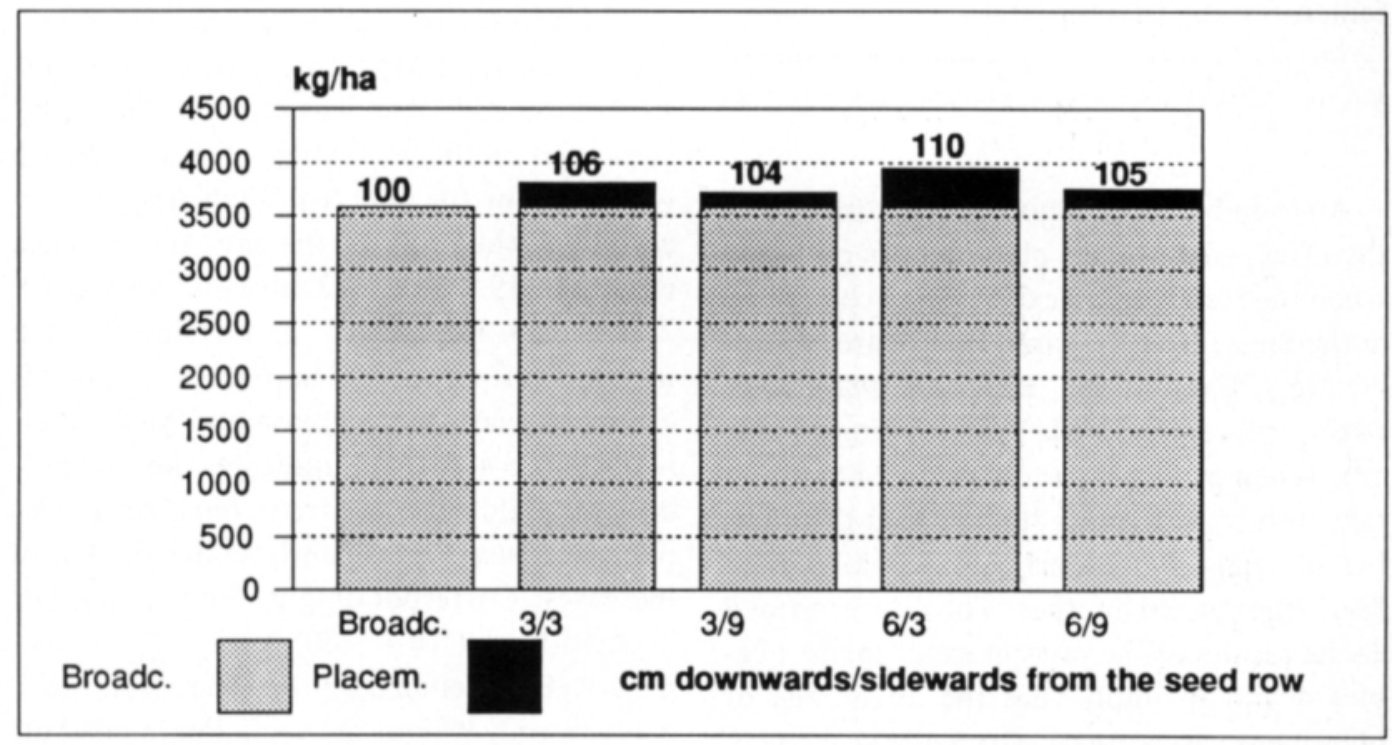

Fig. 9. The effect of the location of the fertilizer row on the recoverable white sugar yield (The fertilizer row on one side of the seed row) (3 trials in 1983-85).

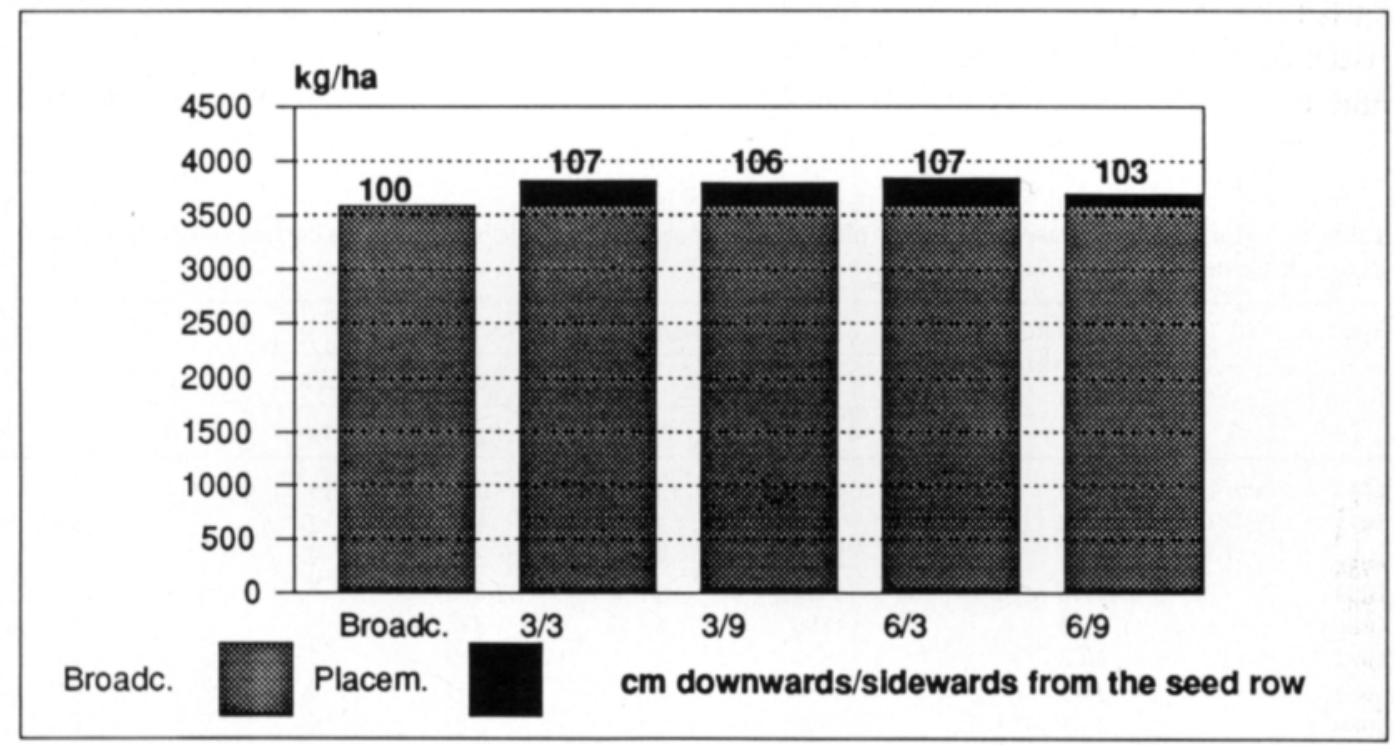

Fig. 10. The effect of the location of the fertilizer row on the recoverable white sugar yield (The fertilizer row on both sides of the seed row) (3 trials in 1983-85). 
$6.4 \%$. In most cases the difference was significant. In individual trials the yield increase ranged from 0 to $24 \%$. By calculating the mean increases for different years as compared to broadcasting (the comparison is based only on those trial members where the fertilizer was placed $3-6 \mathrm{~cm}$ to the side and below the seed) the following figures are obtained for the present trials:

Year $\quad 19821983198419851986198719881989$ Increase $\%+16+4+11+7+12+8+5+3$

An even better and more specific picture of the effect of fertilizer placement is obtained when the results of all experiments conducted at the Sugar Beet Research Centre are considered (e.g. ERJala 1986, RaininKo 1988), comparing placement with broadcasting (Table 10). When evaluating the figures, one should take into consideration the fact that the number of trials and experimental fields varied from one year to another. The figures as well as the results of the present experiments (Tables 4 and 6) imply that the advantage of placement varies greatly from one year to another and from one trial field to another. Similarly, the yield increase obtained by placement fertilization of cereals in Finland has varied from one year to another, ranging between 0 and $40 \%$ (NIEMINEN et al 1967, KARA and RĂISÃNEN 1974). The highest yield in- creases for sugar beet were obtained in 1982, 1984, 1986 and 1987 which, except for 1986, were the coldest years of the experimental period, when the yield levels were rather low. When all fertilizer placement trials are considered (Table 10), the effect of placement during the coldest summer of 1987 was not exceptionally great.

The lowest percentage increase was, however, recorded in the high yielding years of 1983, 1989 and 1990. The effect of years and yield level on the percentage of yield increase was tested by the analysis of covariance. According to the analysis, the annual difference explained $19.7 \%\left(\mathrm{~F}=2.20^{*}\right)$ and yield level $24.8 \%\left(\mathrm{~F}=3.92^{* * *}\right)$ of the variance in yield increase (in percent). The regression coefficient between yield increase and yield level, $-0.476\left(\mathrm{t}=4.701^{* * *}\right)$, indicates that the percentage yield increase from fertilizer placement decreases significantly as the yield level increases. Correspondingly, the increase per hectare $\mathrm{kg} / \mathrm{ha}\left(\mathrm{b}=-80, \mathrm{t}=2.63^{*}\right)$ is also negatively dependent on the yield level, but it explains only $9 \%$ of the variation in yield increase $\left(\mathrm{F}=2.35^{*}\right)$.

Several researchers have shown that placement of fertilizer clearly accelerates germination and results in yield increases, especially on soils deficient in nutrients (LUDECKE et al. 1956, Shotton 1962, Andersson and Pet-

Table 10. Mean yield increase by fertilizer placement compared to broadcasting in trials carried out by Sugar Beet Research Centre in 1982-90.

\begin{tabular}{|c|c|c|c|c|c|c|}
\hline \multirow[t]{3}{*}{ Year } & \multirow{3}{*}{$\begin{array}{c}\text { Root yield } \\
\text { Broadcasting } \\
\text { t/ha }\end{array}$} & \multicolumn{4}{|c|}{ Placement : Yield increase } & \multirow[t]{3}{*}{ No. of trials } \\
\hline & & \multicolumn{2}{|c|}{ Root yield } & \multicolumn{2}{|c|}{ Recoverable sugar } & \\
\hline & & $\mathrm{kg} / \mathrm{ha}$ & $\%$ & $\mathrm{~kg} / \mathrm{ha}$ & $\%$ & \\
\hline 1982 & 31.3 & 4100 & 13 & 702 & 15 & 2 \\
\hline 1983 & 42.2 & 840 & 2 & 123 & 2 & 10 \\
\hline 1984 & 32.1 & 2890 & 9 & 387 & 9 & 11 \\
\hline 1985 & 27.2 & 1630 & 6 & 228 & 7 & 15 \\
\hline 1986 & 31.3 & 1880 & 6 & 382 & 8 & 10 \\
\hline 1987 & 20.8 & 830 & 4 & 132 & 5 & 7 \\
\hline 1988 & 36.1 & 2180 & 6 & 353 & 8 & 8 \\
\hline 1989 & 43.3 & 1300 & 3 & 249 & 4 & 2 \\
\hline 1990 & 40.0 & 1200 & 3 & 230 & 4 & 3 \\
\hline \multicolumn{2}{|c|}{ Mean or together } & 1684 & 5.7 & 310 & 6.9 & 68 \\
\hline
\end{tabular}


TERSSON 1977). In Finland, the largest yield increases for spring cereals have also been obtained by fertilizer placement on soils of poor nutrient status (KIVI and Hovinen 1969, PAUlAmĀKI and LuOSTARINen 1971). For sugar beet the yield increase from placement did not, however, correlate significantly with the nutrient status and humus content of soil as calculated by the multiregression and covariance analysis (59 trials in 1982-1989), although the negative correlation between yield increase and phosporus content of the soil was almost significant $(\mathrm{P}=0.068)$. Instead, the yield increase from placement was positively correlated with soil $\mathrm{pH}$ (yield increase 4.2 percentage points per $\mathrm{pH}$ point, $\mathrm{t}=2.51^{*}$ explains $6.9 \%$ ). These trials did not clearly show the effect of the nutrient status of the soil because the nutrient status of most experimental fields was good or very good and the $\mathrm{pH}$ was high. The positive correlation with $\mathrm{pH}$ is apparently due to the fact that the local lowering of soil $\mathrm{pH}$ near the fertilizer row by placement improved the uptake of manganese by sugar beet on highly limed sugar beet fields (VоTH and Christenson 1980, Erjala 1986).

The yield increase from fertilizer placement in the experiments of 1982 and 1987-1989 on seed bed preparation and fertilization methods was clearly due to the amount of fertilizer applied (Tables 3 and 7). The largest yield increase was obtained with a small amount of fertilizer. In 1983 - 1985, on the other hand, the yield increase in the trial concerning the amount of fertilizer and methods of application was almost the same with all methods of application (Fig. 2).

The effect of sowing time on yield increase from fertilizer placement cannot be established on the basis of the present experiments. Previously reported results (RAININKO 1988) indicate that the advantage of fertilizer placement has been greater when sowing was early than when sowing occurred at the normal time.

In the present trials, fertilizer placement al-

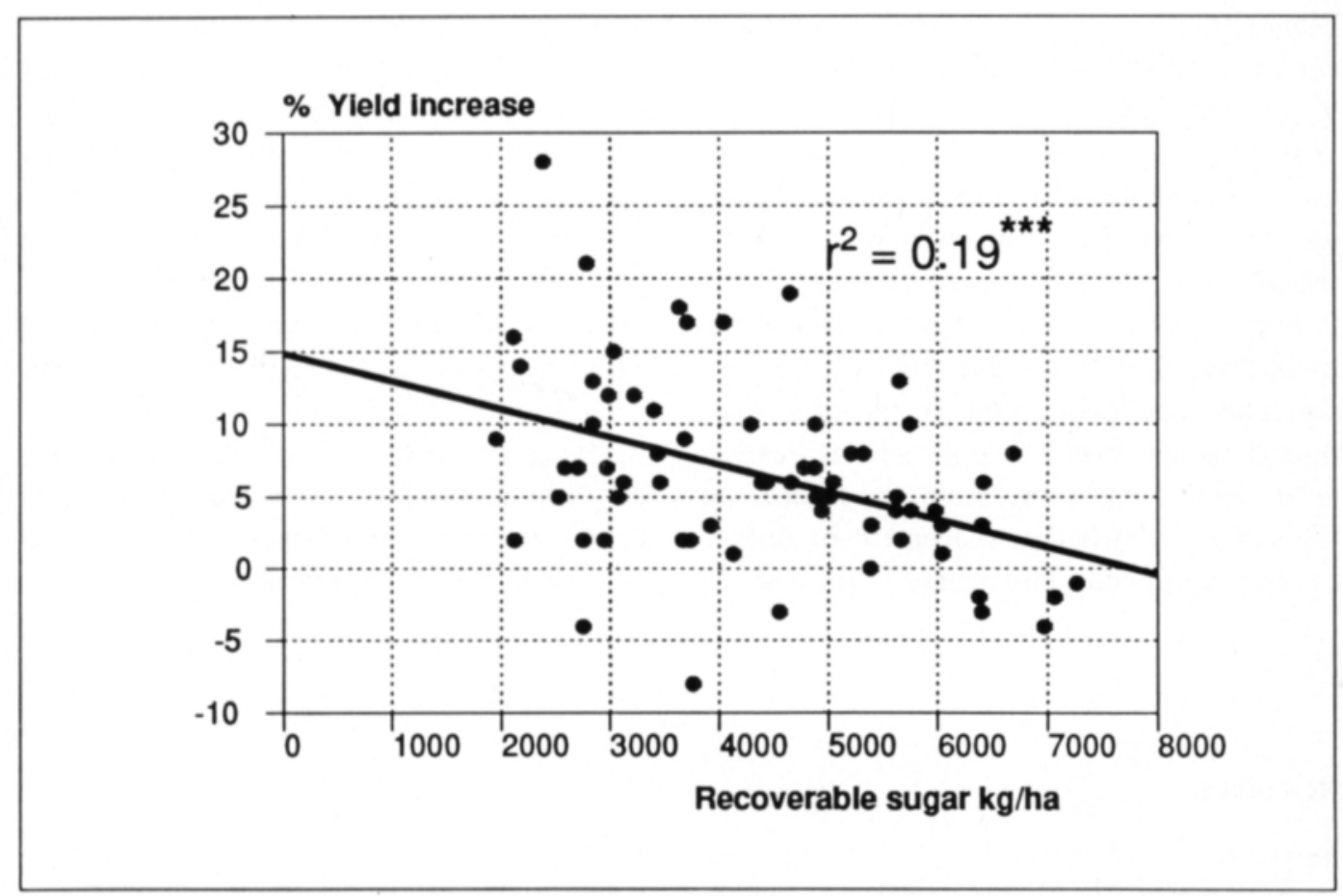

Fig. 11. The correlation between the recoverable sugar and the yield increase by fertilizer placement, $y=14.8763-$ $0.0019 x$ (64 trials in 1982-90). 
most invariably caused a slight increase in the sugar content of sugar beet and in the percent extraction. The latter increase is due to the slightly lower potassium content in the sugar beet. For the above reasons, the sugar content and recoverable sugar yield are increased by fertilizer placement slightly more than root yield is increased. The increase in recoverable sugar yield from fertilizer placement varied in different trials and in different years, in a manner very similar to the root yield increases. However, the percentage increase in recoverable sugar yield (Fig. 11) correlated with yield level less $\left(\mathrm{b}=-0.0019, \mathrm{t}=3.71^{* * *}\right)$ than the yield increase of root yield. The mean yield increase in different years was $310 \mathrm{~kg} / \mathrm{ha}$ recoverable sugar, or $6.9 \%$.

In the present experiments, the increases obtained with fertilizer placement were of the same magnitude as in Sweden in 1981-1982 (TronNBerg 1983), but slightly higher than those reported earlier in central Europe (LudecKe et al. 1955, ShotTon 1962). In recent years, attention has again been paid to fertilizer placement in sugar beet cultivation, because this is assumed to result in the present yield level with lower fertilization levels. Experiments conducted in Denmark in 19881989 indicated that fertilizer placement would give the same yield with approximately $20 \%$ less fertilizers than used with broadcasting (Marcussen 1989). The present trials (Table 9, Figs 5 and 8) also show that fertilizer placement gives the same sugar yield with a considerably smaller amount of fertilizer than does broadcasting. The optimal fertilization level would, however, seem to remain on the same level whether placement or broadcasting is applied. Thus there is no need to change the fertilization recommendations when converting from broadcasting to placement.

Placement of the fertilizer too close to the beet seed, which causes an excessive increase in the salt concentration of soil water, may inhibit germination of the sugar beet seed. According to COOKE $(1949,1951), 2^{\prime \prime}$ to the side and 2 " ' below the seed is a safe distance. In trials in Perniö the placement of the fertilizer $3 \mathrm{~cm}$ to the side of the seed has not been harmful. Placement of the fertilizer $9 \mathrm{~cm}$ to the side of the seed, however, gave a clearly poorer yield than placement at a distance of $3 \mathrm{~cm}$. It was clearly visible from the colour of the plants that it took quite long before the plants were able to take up a fertilizer placed this far away. Inversely, the depth of the fertilizer ( 3 or $6 \mathrm{~cm}$ below the seed) had no significance. According to ANDERSON and Peterson (1977), the root system of sugar beet grows downwards rapidly, and five days after germination it is already able to take up nutrition from a depth of $2^{\prime \prime}$; the same distance horizontally takes almost three times more time. Although placement of the fertilizer $3 \mathrm{~cm}$ to the side of the seed did not cause any germination disturbances in these trials, it soon became evident in practice that a fertilizer placed this close might retard the emergence of the sugar beet. This is probably due to the excessively high salt concentration of soil water near the fertilizer row and the seed bed being broken by the fertilizing bill. When, in addition to this, the position of the fertilizing and sowing bills may vary to some extent during sowing, it is concluded that placement $5-6 \mathrm{~cm}$ to the side and $3-4 \mathrm{~cm}$ below the seed can be recommended.

\section{References}

Andersson, F.N. \& Peterson, G.A. 1977. Optimum starter fertilizer placement for sugar beet seedlings as determined by uptake of radioactive ${ }^{32} \mathrm{P}$ isotope. $\mathrm{J}$. Am. Soc. Sug. Beet Tech. 20: 19-24.

ANon 1970. Lannoitteen sijoittaminen. SvT:n tietokortisto $1970,2, \mathrm{E}, 11$.

COOKE, G.W. 1949. Placement of fertilizer for row crops. J. Agric. Sci. Camp. 39: 359-373. 
- 1951. Placement of fertilizer for sugar beet. J. Agric. Sci. Camp. 41: 174-178.

Draycott, A.P. 1972. Sugar beet nutrition 250s, London.

ERJALA M. 1984. Sokerijuurikaspellon kevättyöt tutkimuksen kohteena. Juurikas 1984, 1: 4-8.

- 1986. Control of manganese deficiency in sugar beet by placement of a manganated compound fertilizer. J. Agric. Sci. Fin. 58: 215-220.

— \& RAININKo, K. 1985. Sådd av sockerbetor på lerjord med en köring. Betan 1985, 2: 13-17.

KARA, O. \& RĀISĀNEN, L. 1974. Sijoituslannoituksen kehityksestä ja tutkimustoiminnasta Suomessa. Sum. On the development of field experiments of fertilizer placement in Finland. J. Scient. Agric. Soc. Finl. 46: $175-184$.

Kıvı, E. \& Hovinen, S. 1969. Lajikkeen ja lannoitustavan vaikutus kevătvehnăn viljelyarvoon. J. Scient. Agric. Soc. Finl. 41: 258-274.

LOdecke, H., Scheffer, F. \& Tiedemann, H.-G. 1956. Der Einfluss der Reihendüngung auf Ertrag und Qualităt der Zuckerrübe. Zucker, 9: 30-36.

\section{SELOSTUS}

\section{Lannoitteen levitystavan vaikutus sokeri- juurikkaan satoon, sadon laatuun ja lannoitustarpeeseen Suomessa}

\section{Kyösti Raininko \& Matti Erjala \\ Sokerijuurikkaan Tutkimuskeskus}

Sokerijuurikkaan Tutkimuskeskus on vuosina 1982-90 jărjestănyt kaikkiaan 68 sijoituslannoituskoetta, joista tăssă tutkimuksessa on selostettu 5 eri koesarjaan kuuluvat 23 koetta. Tulosten tarkastelussa on käytetty hyväksi myös tutkimuskeskuksen muista kokeista saatuja tuloksia. Kenttäkokeet on tehty tutkimuskeskuksen ja sokeritehtaiden koetiloilla (kuva 2). Koekenttien maalaji vaihteli tiiviistă savesta hietaan. Maiden $\mathrm{pH}$ oli korkea $(6.7-7.4)$ ja ravinnetila hyvä. Lannoitteena kăytettiin natriumpitoista Y-lannosta, jonka koostumus v. 1982 - 87 oli järjestyksessă N, P, K, Na 13-6-9-6 \% ja vuodesta 1987 15-6-8-5 \%. Lannoite sijoitettiin rivilannoittimella, johon liitettiin kylvőyksikőt. Vuosina 1982 ja -83 kăytettiin lannoitevantaina lautasvannasta, myöhemmin kapeata vetovannasta.

Lannoitteen sijoittaminen 3-6 cm siemenrivin sivulle ja $3 \mathrm{~cm}$ sen alapuolelle lisäsi sokerijuurikkaan juurisatoa keskimäärin 5-6 prosenttia hajalevitykseen verrattuna. Sadonlisăys vaihteli $0-24$ prosenttiin (taulukot 3-10). Sijoituslannoituksella saatu sadonlisäys korreloi
Marcussen, C. 1989. Gődningsförsög 1989. Dyrkningsförsög og undersögelser i sukkerröer 1989: 13-29.

Nieminen, L., Kara, O. \& Elonen, P. 1967. Kokemuksia sijoituslannoituksesta. Maatal. ja koetoim. 21: 42-49.

Paulamäkı, E. \& Luostarinen, H. 1971. Fertilizer drilling on peat soils. Acta Agr. Fenn. 123: 167-172.

RAININKO, K. 1981. Markstruktur, bearbetning och gödsling efter en regnerik sommar. Betan 81, 4: $21-23$.

- 1988. Seed bed preparation and simultaneous placement of fertilizer in one operation to save costs and increase yield. I.I.R.B. 51 ${ }^{\mathrm{e}}$ Congres d'hiver 23-32.

SноттоN, F.E. 1962. Placement of fertilizer for sugar beet. Expl. Husb. 7, 8-16.

TrönNBERG, F: 1983. Högre skörd med radmyllning av kväve. Betodlaren 47: 24-26.

Voth, R.D. \& Christenson, D.R. 1980. Effect of fertilizer reaction and placement on availability of manganese. Agr. J. 72: 769-773.

Ms received Jan 15, 1991

negatiivisesti juurikkaan satotason kanssa. Maan ravinteisuus, humuspitoisuus ja maalaji eivăt vaikuttaneet sijoituslannoituksella saatuun sadonlisäykseen.

Maan muokkaustavalla - jyrsinmuokkaus ja yksi ajokerta tai useampi äestys - ei ollut merkitsevăă vaikutusta sijoituslannoituksella saatuun sadonlisăykseen (taulukko 7).

Lannoitustason nostaminen vähensi osassa kokeita sijoituksesta saatavaa sadonlisăystă (taulukot 3 ja 7). Aina ei kuitenkaan näin tapahtunut (kuva 3).

Sijoituslannoituksella saatiin sama tai hiukan parempi sokeripitoisuus kuin hajalevityksellä (taulukot 3 ja 7 , kuva 4).

Sijoituslannoitus alensi lievăsti juurikkaan kaliumin pitoisuutta ja kohotti sokerin saantoa (taulukot 2, 5 ja 8 , kuvat 3 ja 7). Sijoituslannoitus hajalevitykseen verrattuna lisäsi kiteytyvăă sokerisatoa suhteellisesti jonkin verran enemmän kuin juurisatoa (taulukot 2,5 ja 7 , kuvat 6 ja 9).

Lannoitteen sijoittaminen $3 \mathrm{~cm}$ siemenrivin sivulle ja 
3 tai $6 \mathrm{~cm}$ sen alapuolelle antoi paremman tuloksen kuin $9 \mathrm{~cm}$ sivulle sijoitettuna (taulukko 9). Sijoitussyvyydellă ei ollut vaikutusta satoon.

Lannoitteen sijoittaminen on useimmissa kokeissa hyvin lievästi văhentănyt juurikkaan yksilömăărăả hajalevitykseen verrattuna. Haitta ei näissă kokeissa ole ollut mer- kitsevă käytettăessă pienintăkăăn $3 \mathrm{~cm}$ etăisyyttă siemenrivistă. Kăytănnőssă on kuitenkin joskus todettu liian lăhelle sijoitetun lannoitteen estävăn tai hidastavan juurikkaan itämistä, siksi lannoite suositellaankin sijoitettavaksi $5-6 \mathrm{~cm}$ siemenrivin sivulle ja $3-4 \mathrm{~cm}$ sen alapuolelle. 